\title{
Taxonomic relevance of the gametophytic generation in a strictly rupicolous fern group: Asplenium seelosii s.l.
}

\author{
EMILIA PANGUA*, LUIS G. QUINTANILLA $\dagger$ and SANTIAGO PAJARÓN \\ Departamento de Biología Vegetal I, Facultad de Biología, Universidad Complutense, Ciudad \\ Universitaria, 28040 Madrid, Spain
}

Received February 2005; accepted for publication October 2005

\begin{abstract}
The systematics of the Asplenium seelosii complex has been debated for a long time. This complex includes strictly rupicolous plants that live on limestone cliffs mainly in the mountains of south-west Europe: the Alps, the Pyrenees, and several mountain ranges of the eastern Iberian Peninsula. The disjunct distribution of its populations and several morphological characters, i.e. leaf indumentum and the structure of the perispore, have been used to distinguish two species and up to four subspecies. The goal of this study was to determine whether the characters of the gametophytic generation and young sporophytes can contribute to the recognition of the proposed taxa. The analysis of all of these characters together differentiated two groups that correspond to the established species, A. seelosii and A. celtibericum, but not enough differences were found to separate the subspecies in each of them. (C) 2006 The Linnean Society of London, Botanical Journal of the Linnean Society, 2006, 151, 375-386.
\end{abstract}

ADDITIONAL KEYWORDS: Aspleniaceae - Asplenium celtibericum - gametophyte morphology - sex expression - sporelings - systematics.

\section{INTRODUCTION}

The systematics of the Asplenium seelosii complex has been discussed for a long time. Plants of A. seelosii s.l. are diminutive and the leaves consist of a relatively long green petiole and a small lamina which may vary from entire to divided into three separated segments. The group occupies a fragmented area with three main centres: the southern Alps and surrounding regions, the Pyrenees, especially in their eastern part, and the eastern half of the Iberian Peninsula. Based on the presence or absence of glandular hairs, some authors have recognized two subspecies within A. seelosii: ssp. glabrum (Litard. \& Maire) Rothm. and ssp. seelosii (Rothmaler, 1937; Nogueira \& Ormonde, 1986; Viane, Jermy \& Lovis, 1993). Starting with this indumentum distinction, Rivas-Martínez (1967) used leaf morphology and ecological differences to separate the Iberian plants as a new species, A. celtibericum

*Corresponding author. E-mail: epangua@bio.ucm.es †Current address: Departamento de Matemáticas y Física Aplicadas y Ciencias de la Naturaleza, Universidad Rey Juan Carlos, C/Tulipán s/n, 28933 Móstoles, Madrid, Spain
Rivas-Martínez. Lovis (1987) carried out cytological research on experimental hybrids between plants from the Alps and plants from the eastern Pyrenees, and demonstrated the close relationship between these entities. Moreover, plants living in the Pyrenees, in north-east Spain and south-east France, are similar to plants from the Alps in their mainly divided leaves. The remaining Spanish plants have mostly entire leaves, and show differences in the perispore (Pangua, 1989). Because of this variation Cubas, Pardo \& RivasMartínez (1993) extended the analysis of spore features by adding a detailed study of the perispore ornamentation and the spore wall structure. As a consequence of their study, and an evaluation of macromorphology, ecology, and biogeography, Cubas et al. (1993) proposed a new subdivision of the aggregate into two species with two subspecies each. Thus, the proposed systematics of the group are as follows:

Asplenium seelosii Leybold

ssp. seelosii, from the Alps and neighbouring areas. ssp. catalaunicum (Bolòs \& Vigo) Montserrat, from the eastern Pyrenees (north-east Spain and south-east France). 


\section{Asplenium celtibericum Rivas-Martínez}

ssp. celtibericum, from the eastern half of the Iberian Peninsula and northern Morocco.

ssp. molinae Cubas, Pardo \& Rivas-Martínez, from the central Pyrenees (north-east Spain).

A revision of the taxonomic background of the group is given in Reichstein (1984), Lovis (1987), and Cubas et al. (1993). However, no general agreement has yet been reached about the classification of this complex (Prelli, 2001).

Traditionally, the systematics of ferns was based mainly on the morphology of the sporophyte. In the last 30 years, biochemical and molecular techniques have been used to help in the clarification and understanding of the relationships between taxa, and even in the recognition of species (e.g. Werth, Guttman \& Eshbaugh, 1985; Ranker et al., 1989; Pryer \& Haufler, 1993; Van den heede, Viane \& Chase, 2003). Recently, Pajarón, Quintanilla \& Pangua (2005) used isoenzyme electrophoresis to clarify the systematics of the A. seelosii complex. Nevertheless, characters of the gametophyte have been proven to contribute to the differentiation at the species level of some taxa (Nayar, Raza \& Lata, 1968; Prada et al., 1996; Chiou, Farrar \& Ranker, 1998; Mendoza-Ruiz \& Pérez-García, 2003; Pangua et al., 2003). Although they are very simple, some of their attributes can be used, such as the type of initial development, the presence or absence of hairs and their features (i.e. length, shape, number of cells, density, location), the morphology of gametangia, and the sex sequence that is related to the breeding system (Stokey, 1951; Nayar \& Kaur, 1971; Raghavan, 1989; and references cited therein). Characters of the sporelings and young sporophytes have usually been included in studies of the gametophytic generation.

In this study, we investigate some morphological and reproductive aspects of the gametophyte generation in A. seelosii s.l. Concretely, we studied the prothallial development, the morphology of the sexually mature gametophyte, and the sequence of appearance of gametangia, all of which had not been studied before in this group. We also examined some characters of sporelings and young sporophytes. Our final aim was to utilize all of these characters to test the proposed division of the aggregate into two species with two subspecies each.

\section{MATERIAL AND METHODS}

Populations in the distribution area of each of the subspecies were selected (Table 1). Only one population of A. celtibericum ssp. molinae was used. This subspecies is only known from two sites: the area from which we collected the SOL population, and another limestone range, Sierra de Guara, where it might be extinct.

Spores from ten individual plants of each population were used to obtain gametophytes. The only exception was the FON population, for which only three individuals were used.

Table 1. Populations from which spores were collected and their germination percentages. Subspecies according to Cubas et al. (1993). All vouchers are in MACB

Subspecies/ acronym Locality, altitude, collection date and collectors

Germination

$(\%)$

\section{A. celtibericum ssp. celtibericum}

BER Spain: Soria, Plana de Beratón, 1450 m, 30.ix.1999, S. Pajarón \& E. Pangua 92

CAM Spain: Guadalajara, Campisábalos, 22.ix.1999, 1370 m, S. Pajarón \& L. G. Quintanilla 99

GRA Spain: Segovia, Grado del Pico, 22.ix.1999, 1325 m, S. Pajarón \& L. G. Quintanilla 99

SOM Spain: Guadalajara, Somolinos, 1340 m, 3.vii.1999, J. M. Iriondo, M. J. Albert, S. Pajarón 72 \& E. Pangua

A. celtibericum ssp. molinae

SOL Spain: Huesca, Peña Solana, 7.x.1999, 1660 m, S. Pajarón, E. Pangua, \& L. G. Quintanilla

A. seelosii ssp. seelosii

FON Italy: Fortogna-Belluno, $445 \mathrm{~m}, 4 . \mathrm{ix} .1998$, C. Argenti

LOG Italy: Longarone-Belluno, $690 \mathrm{~m}, 9 . \mathrm{ix} .1998$, C. Argenti

LOM Italy: Lombardía, Varese, Valganna, 415 m, 24.viii.1998, A. \& G. Peroni, S. Pajarón \&

$$
\text { E. Pangua }
$$

A. seelosii ssp. catalaunicum

BAG Spain: Barcelona Province, between Bagá and Greixá, 1000 m, 6.x.1999, S. Pajarón, E. Pangua, \& L. G. Quintanilla

ORG Spain: Lérida Province, Organya, Segre river canyon, 5.x.1999, S. Pajarón, E. Pangua, \& L. G. Quintanilla

2

9

2




\section{CULTURE MEDiA}

Cultures were always prepared in sterile Petri dishes of $6 \mathrm{~cm}$ in diameter; two different culture media were used: mineral agar (Dyer, 1979) with Nystatin $100 \mathrm{U} \mathrm{mL}^{-1}$ added as a fungicide; a $3: 1$ soil mixture of compost and sand, devitalized in an autoclave $\left(125^{\circ} \mathrm{C}\right.$ for $20 \mathrm{~min}$ ).

Once sown, the dishes were sealed with 'Parafilm', and placed in a growth cabinet at $21^{\circ} \mathrm{C}$ with a 12 -h light/12-h dark photoperiod (daylight fluorescent tubes; photon irradiance, $30 \mu \mathrm{mol} \mathrm{m} \mathrm{m}^{-1}$ in the $400-$ $700 \mathrm{~nm}$ region).

\section{GERMINATION}

To study germination, spores from ten sporophytes from each population were sown on mineral agar dishes. Two replicates from each population were sown. In all cases, the germination percentages were calculated by counting 50 spores from each dish, and expressed as the mean value of the two dishes. Germination was scored as spores in which the first rhizoid had emerged.

\section{GAMETOPHYTE DEVELOPMENT, MORPHOLOGY, AND SEX EXPRESSION}

The initial development of gametophytes was studied on the same agar dishes as for the germination percentages. About 25 prothalli were randomly sampled weekly, fixed in a mixture of aceto-carmine and chloral-hydrate (Edwards \& Miller, 1972), and heated in a water bath at $50{ }^{\circ} \mathrm{C}$ for $2 \mathrm{~h}$. Prothalli were rinsed with distilled water, mounted on a slide, and examined under a light microscope. After 20 weeks, ten gametophytes per population were randomly selected from the weekly sample to measure marginal hair length and density. Length was calculated by measuring ten hairs, five from each of the wings, from each of the ten gametophytes, and expressed as the mean value of the 100 hairs. Density was estimated by counting the number of hairs in $1 \mathrm{~mm}$ in the same ten gametophytes used for hair length; counts were made in both wings of each gametophyte. Analysis of variance (Zar, 1996) was carried out to reveal statistically significant differences in gametophyte hair length and hair density between populations. A Tukey test $(P<0.05)$ was performed to compare population means (Zar, 1996). These statistical analyses were performed with the program SPSS (1999). Notch area shapes were recorded as V- or U-shaped according to the angle of the sinus. Margin outlines were recorded as regular or irregular according to the smoothness or not of the wing margin. Initial sporophytic leaves were classified into three categories based on the number of lobes: entire, bilobate or trilobate.
For the study of sexual expression, the following populations were used: CAM and GRA of A. celtibericum ssp. celtibericum; SOL of A. celtibericum ssp. molinae; LOM and LOG of A. seelosii ssp. seelosii; and BAG and ORG of A. seelosii ssp. catalaunicum. Twenty-seven presexual gametophytes were transplanted to a dish with soil at a constant culture density: five lines with four, six, six, six, and five gametophytes, respectively (approximately one prothallus per square centimetre). Two replicates for each population were made (54 prothalli per population). Every 2 weeks, each of the 54 prothalli was examined on the plate, under a binocular stereoscopic microscope, for the presence of antheridia and archegonia. When necessary, the prothallus was taken from the dish, rinsed with distilled water, mounted in a slide, examined under an optical microscope, and replanted again in the dish. This manipulation did not appreciably damage the prothalli (Pangua et al., 2003). Gametophytes were scored as being presexual, male, female, or bisexual. These cultures were kept for over 12 months.

For comparison with the systematic scheme of Cubas et al. (1993), and with the genetic results of Pajarón et al. (2005), a similarity matrix of the populations was calculated to construct a phenetic tree. The gametophyte characters considered were the number of archegonium neck cells, length and density of hairs, notch area shape, and margin outline. The degree of division of the initial sporophytic leaf was also included. Based on these data, a dendrogram was obtained by the UPGMA method. This analysis was performed with the program NTSYS-pc (Rohlf, 1994).

\section{RESULTS}

\section{SPORE GERMINATION, DEVELOPMENT, AND GAMETOPHYTE MORPHOLOGY}

Spores from all populations germinated 10-14 days after sowing. The general pattern of development was similar for all the samples (Figs 1-6). Spores produced a filament of three to six cells. In the FON, LOG, and LOM populations (A. seelosii ssp. seelosii), the terminal cell of the filament sometimes produced a unicellular hair (Fig. 2), and the cells behind it divided longitudinally to start the bidimensional stage. In the rest of the studied populations, the formation of hairs was delayed until a small plate had formed.

The development of a bidimensional stage occurred in all sampled populations 8-10 days after germination. The meristematic cell was situated laterally in the young plate; further divisions gave rise to a group of small rectangular cells, the apical meristem, that reached a central position as the thallus grew (Figs 46 ). At the same time, new unicellular hairs were pro- 


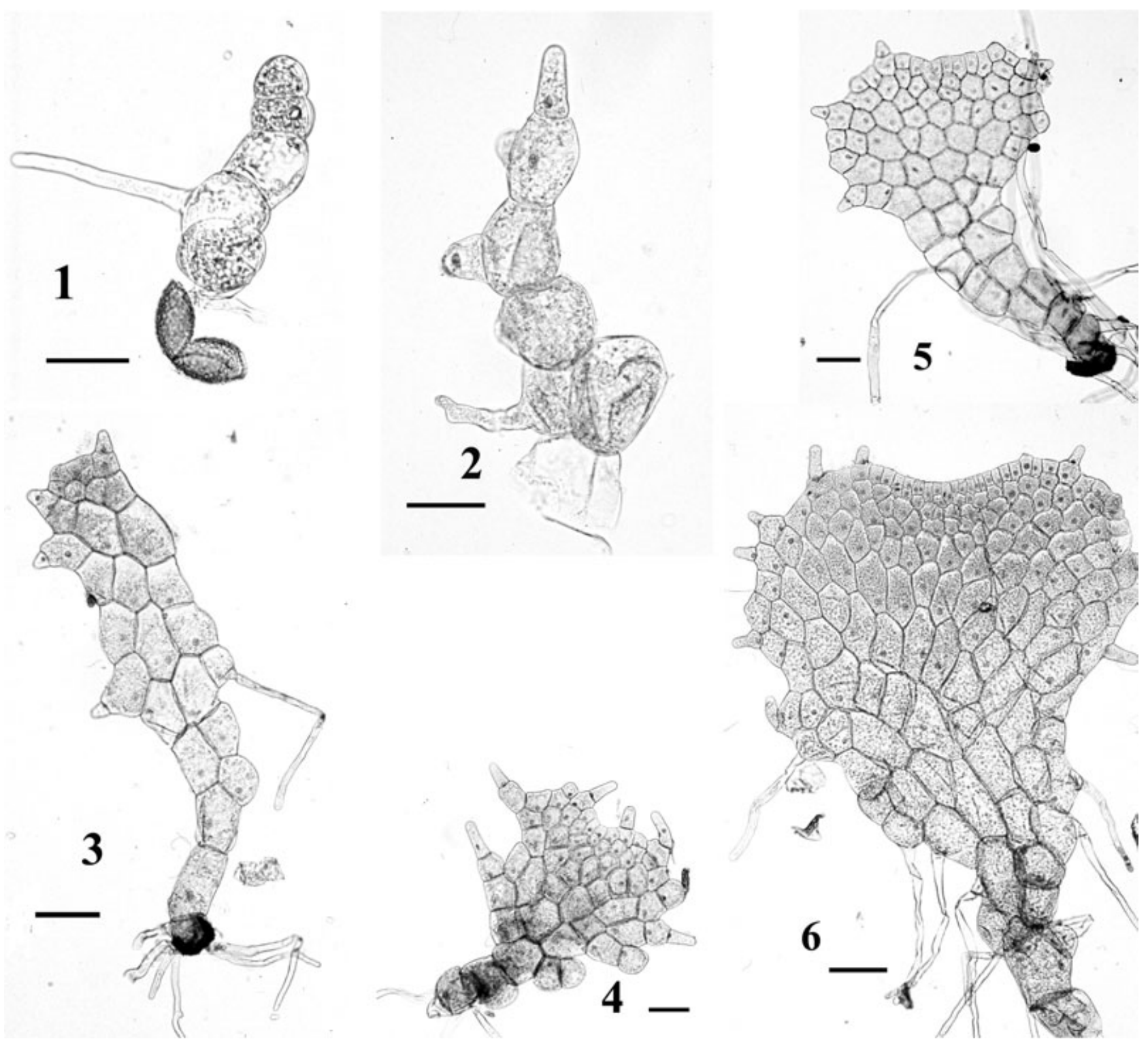

Figures 1-6. Early stages of prothallial development. Fig. 1. Germ filament. Fig. 2. Hair formation in germ filament. Fig. 3. Beginning of laminar stage. Fig. 4. Development of meristematic cells. Figs 5, 6. Young gametophytes with apical notch. Fig. 1. From CAM population (Asplenium celtibericum ssp. celtibericum). Figs 2, 4. From LOM population (A. seelosii ssp. seelosii). Fig. 3. From BAG population (A. seelosii ssp. catalaunicum). Fig. 5. From GRA population (A. celtibericum ssp. celtibericum). Fig. 6. From ORG population (A. seelosii ssp. catalaunicum). Scale bar, $30 \mu \mathrm{m}$.

duced regularly from the meristem and from some cells of the plate margin. In all populations, the adult prothallus was symmetrical and hairy (Figs 7,8 ), but in the FON, LOG, and LOM populations (A. seelosii ssp. seelosii), the wing margin was very irregular (Fig. 7). The apical notch was U-shaped in the FON, LOG, and LOM (A. seelosii ssp. seelosii), BAG and ORG (A. seelosii ssp. catalaunicum), and SOL (A. celtibericum ssp. molinae) populations, and was Vshaped in the BER, CAM, GRA, and SOM populations (A. celtibericum ssp. celtibericum) (Fig. 8). Hairs were mainly unicellular and not secretory (Figs 9-12). In the BER, CAM, GRA, and SOM (A. celtibericum ssp. celtibericum), SOL (A. celtibericum ssp. molinae), and BAG and ORG (A. seelosii ssp. catalaunicum) populations, hairs were more or less triangular in shape, because they were swollen in the basal half. In the FON, LOG, and LOM populations (A. seelosii ssp. seelosii) (Fig. 9), hairs were cylindrical and, exceptionally, bicellular.

The population had significant effects on gametophyte hair length $(F=846.297$, nine degrees of free- 

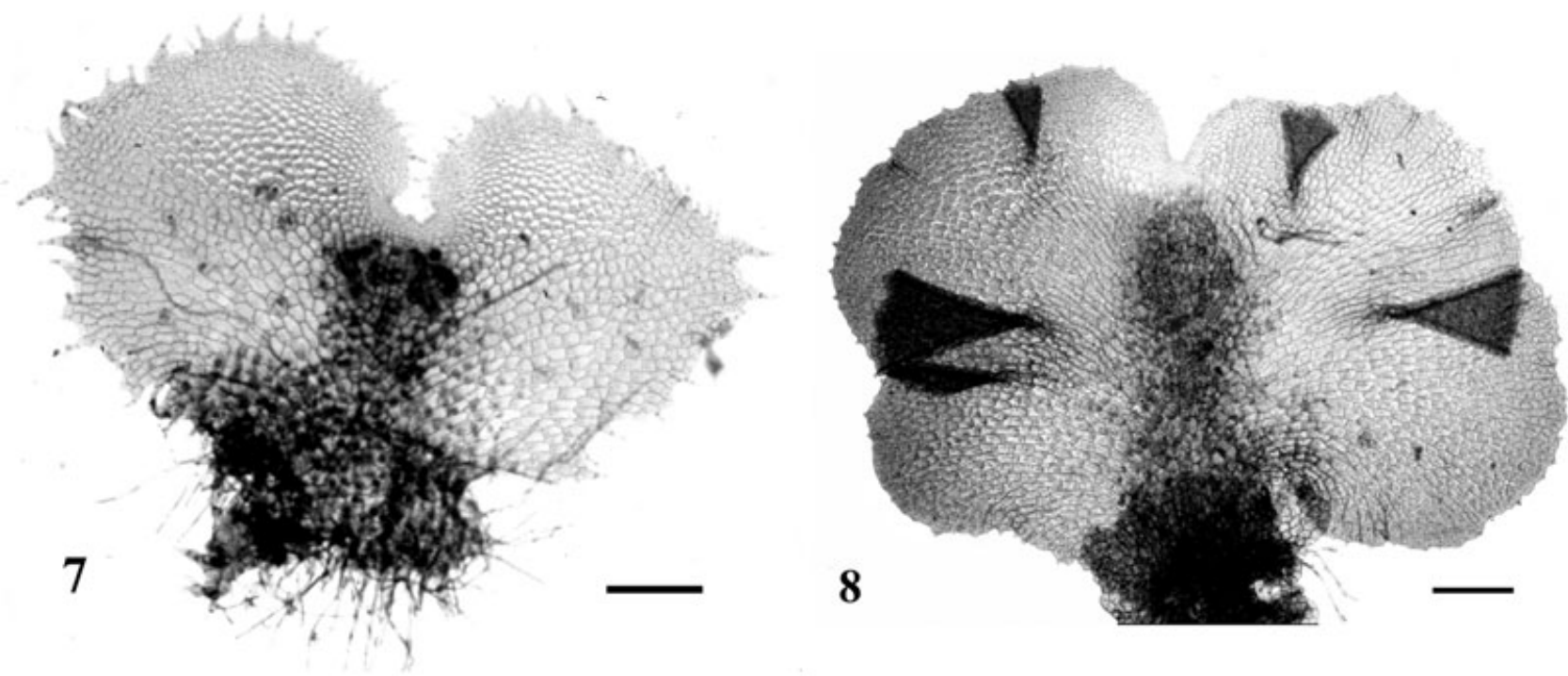

Figures 7, 8. Mature gametophytes. Fig. 7. Female prothallus with irregular margin from LOM population (Asplenium seelosii ssp. seelosii). Fig. 8. Bisexual prothallus with smooth margin from SOM population (A. celtibericum ssp. celtibericum). Scale bar, $25 \mu \mathrm{m}$.

Table 2. Gametophyte hair length and hair density (mean \pm standard error) of the ten populations (in parentheses) of the Asplenium seelosii group. In each column, values with the same lower case letters indicate means that are not significantly different from each other (Tukey test, $P<0.05$ )

\begin{tabular}{lc}
\hline Hair length $(\mu \mathrm{m})$ & Hair density $($ hairs $/ \mathrm{mm})$ \\
\hline $17.8 \pm 0.2(\mathrm{BER}) \mathrm{a}$ & $7.6 \pm 0.3(\mathrm{BER}) \mathrm{a}$ \\
$20.0 \pm 0.3(\mathrm{CAM}) \mathrm{b}$ & $7.7 \pm 0.3(\mathrm{SOM}) \mathrm{a}$ \\
$20.1 \pm 0.3(\mathrm{GRA}) \mathrm{b}$ & $8.1 \pm 0.5(\mathrm{CAM}) \mathrm{a}$ \\
$21.3 \pm 0.3(\mathrm{SOM}) \mathrm{b}$ & $8.4 \pm 0.4(\mathrm{FON}) \mathrm{a}$ \\
$24.4 \pm 0.3(\mathrm{SOL}) \mathrm{c}$ & $10.7 \pm 0.5(\mathrm{GRA}) \mathrm{ab}$ \\
$26.8 \pm 0.4(\mathrm{BAG}) \mathrm{d}$ & $10.8 \pm 0.3(\mathrm{LOG}) \mathrm{b}$ \\
$27.0 \pm 0.3(\mathrm{ORG}) \mathrm{d}$ & $13.8 \pm 0.5(\mathrm{ORG}) \mathrm{c}$ \\
$46.8 \pm 0.6(\mathrm{LOG}) \mathrm{e}$ & $13.9 \pm 0.6(\mathrm{BAG}) \mathrm{c}$ \\
$48.3 \pm 0.7(\mathrm{LOM}) \mathrm{e}$ & $19.2 \pm 0.6(\mathrm{SOL}) \mathrm{d}$ \\
$50.8 \pm 0.7(\mathrm{FON}) \mathrm{f}$ & \\
\hline
\end{tabular}

dom, $P<0.001)$ and hair density $(F=68.384$, nine degrees of freedom, $P<0.001)$. The mean values of these characters for the studied populations are shown in Table 2. Gametophytes of the FON, LOG, and LOM populations (A. seelosii ssp. seelosii) had the longest hairs, whereas the BER, CAM, GRA, and SOM populations (A. celtibericum ssp. celtibericum) had the shortest hairs. The BAG and ORG (A. seelosii ssp. catalaunicum) and SOL (A. celtibericum ssp. molinae) populations showed intermediate hair lengths, although their means were closer to the values of the A. celtibericum ssp. celtibericum popula- tions than to those of the A. seelosii ssp. seelosii populations.

The groups of mean values obtained for hair density were different from those for hair length (Table 2). The two groups with the lowest density values mixed A. celtibericum ssp. celtibericum populations with A. seelosii ssp. seelosii populations, whereas the highest density was found in the BAG and ORG (A. seelosii ssp. catalaunicum) and SOL (A. celtibericum ssp. molinae) populations.

\section{SEX SEQUENCE}

Two months after sowing, the gametophytes started to develop sex organs (Figs 13, 14). In all populations, the mature antheridium (Fig. 13) was globose and consisted of a basal cell, a cylindrical ring cell, and a cap cell. The archegonia in the FON, LOG, and LOM populations (A. seelosii ssp. seelosii) had necks of eight to nine cells (Fig. 14), longer than in the rest of the populations studied (four to five neck cells).

Antheridia appeared first in the CAM and GRA populations (A. celtibericum ssp. celtibericum) in which, 6 months after sowing, nearly $100 \%$ of the prothalli were male (Fig. 15A, B). Two months later, about half of these male prothalli had developed archegonia and were bisexual, whereas the other half remained male. No changes were detected until the end of the experiment 12 months after sowing.

In the BAG and ORG populations (A. seelosii ssp. catalaunicum), the sexual sequence began with male and female gametophytes at low percentages; 8 months after sowing, almost all the prothalli were 

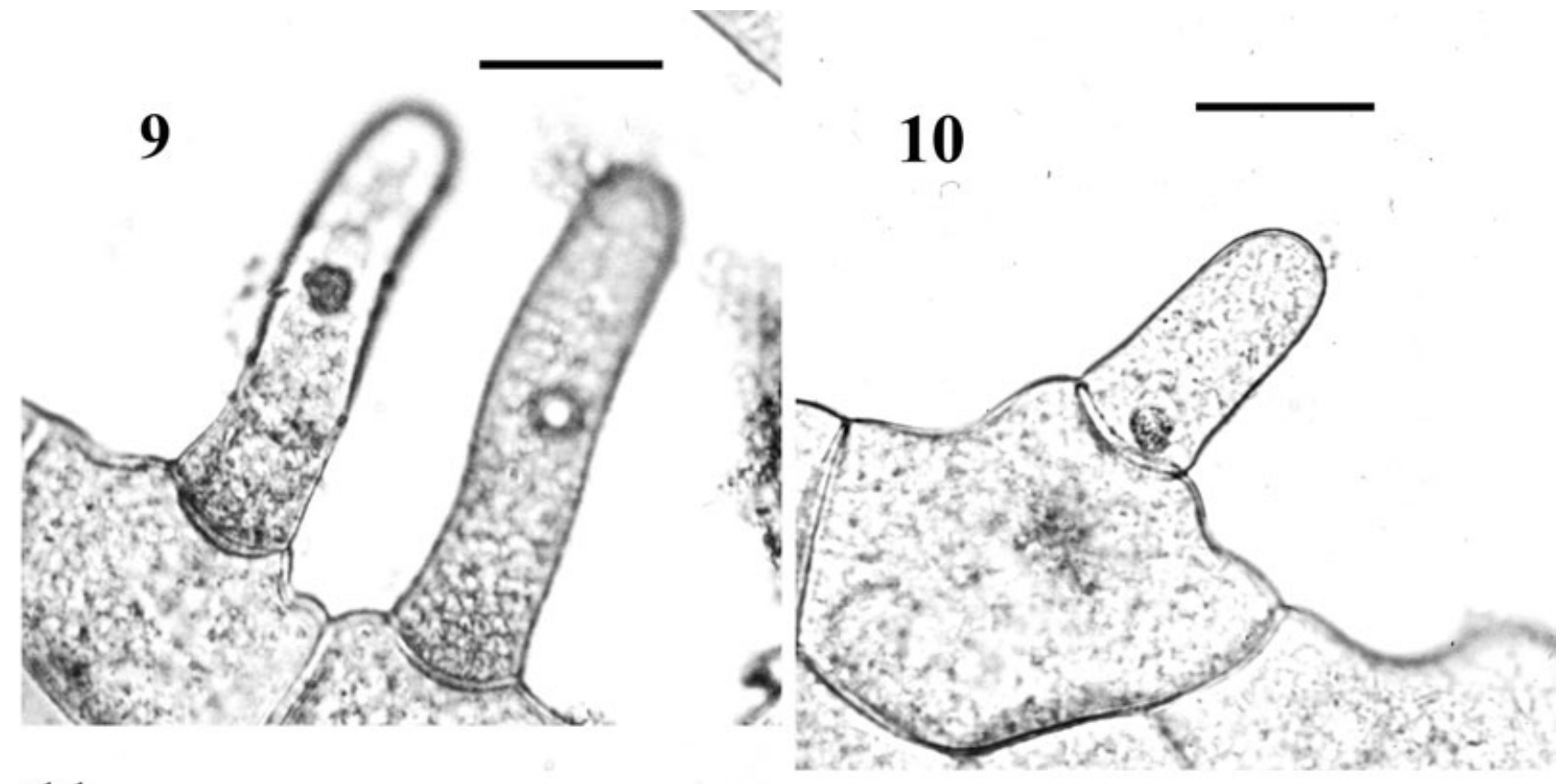

\section{1}

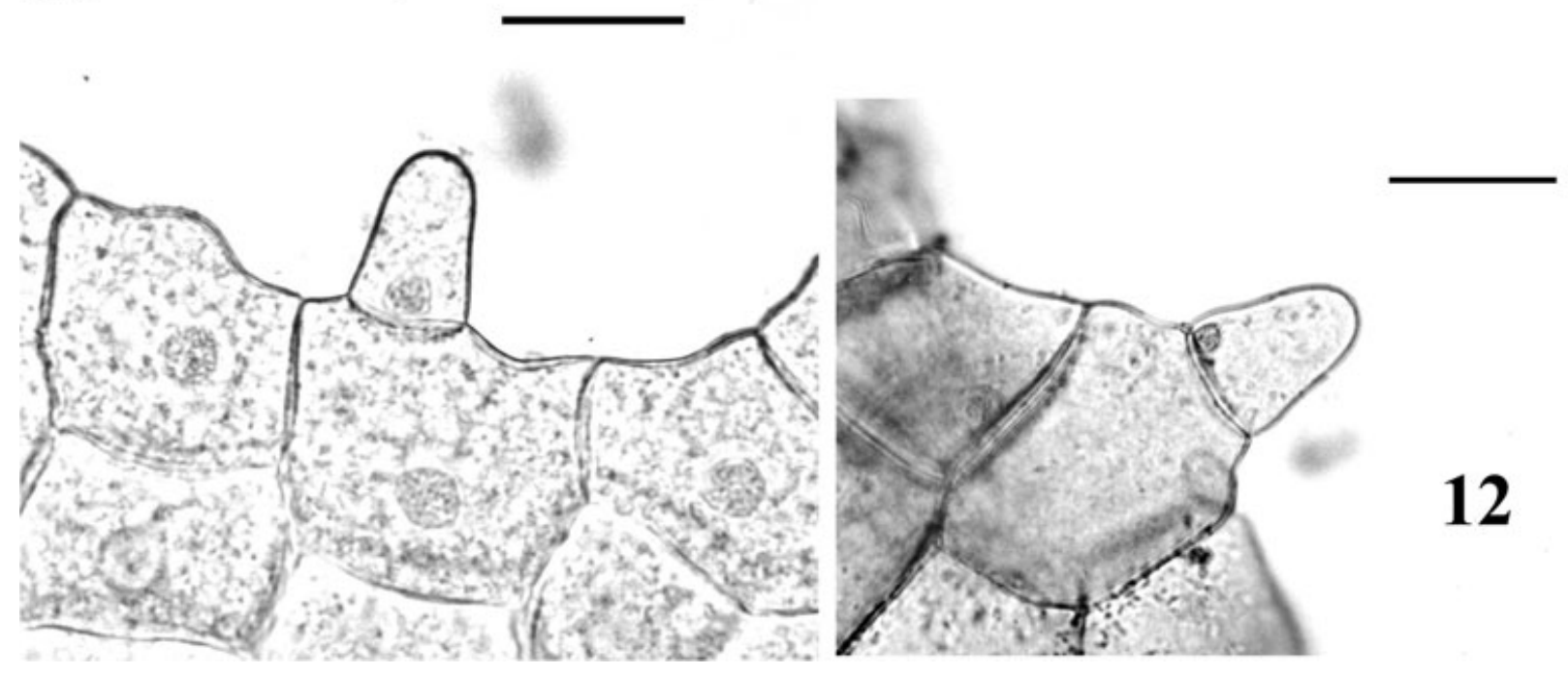

Figures 9-12. Marginal hairs. Fig. 9. From FON population (Asplenium seelosii ssp. seelosii). Fig. 10. From BAG population (A. seelosii ssp. catalaunicum). Fig. 11. From SOL population (A. celtibericum ssp. molinae). Fig. 12. From SOM population (A. celtibericum ssp. celtibericum). Scale bar, $25 \mu \mathrm{m}$.

bisexual (Fig. 15D, E). In the SOL population (A. celtibericum ssp. molinae), male and female gametophytes also appeared first, and, although having a high percentage of bisexual prothalli, female ones remained present until the end of the experiment (Fig. 15C). In the LOM population (A. seelosii ssp. seelosii), the sexual sequence began with the appearance of archegonia, and female gametophytes reached a high percentage after 6 months (90\%); afterwards, many of these became bisexual and, at the end of the experiment, most of the prothalli, about $80 \%$, were bisexual (Fig. 15F). Most of the gametophytes from the LOG population (A. seelosii ssp. seelosii) produced archegonia from the beginning of the culture, but we did not find any male or bisexual prothalli (for this reason, the graph of this population has not been included).

In all cultures, each prothallus gave rise to colonies as a result of continuous vegetative proliferations that remained attached to the parent thallus. Many of these proliferations developed antheridia and some also archegonia. 


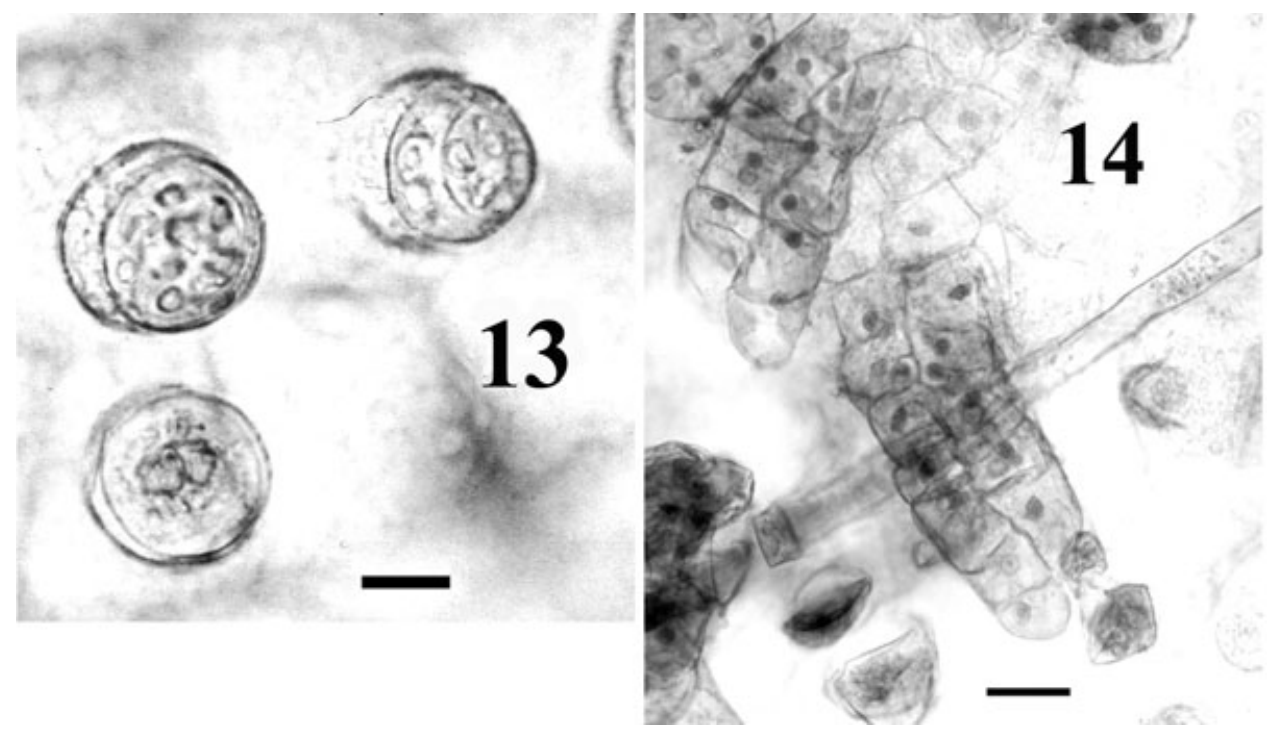

Figures 13, 14. Gametangia. Fig. 13. Antheridia with three cells from SOL population (Asplenium celtibericum ssp. molinae). Fig. 14. Archegonia with long necks from LOM population (A. seelosii ssp. seelosii). Scale bar, $20 \mu \mathrm{m}$.

Young sporophytes started to appear 6 months after sowing in all populations. The percentages of fertilized archegoniate prothalli are given in Figure 16. The number of sporophytes formed was different for taxa and populations. The highest percentage of sporophytes was found in the ORG population (A. seelosii ssp. catalaunicum), and the lowest in the LOM population (A. seelosii ssp. seelosii). All fertilized gametophytes were bisexual and, in several cases, polyembryony was observed. Juvenile sporophytes had some morphological differences (Fig. 17A-D). The first leaves of sporelings in the CAM and GRA (A. celtibericum ssp. celtibericum) and SOL (A. celtibericum ssp. molinae) populations were more or less entire and spatulate, and became bilobate in successive leaves as the sporeling grew. In the BAG and ORG (A. seelosii ssp. catalaunicum) and LOM (A. seelosii ssp. seelosii) populations, the first leaves of sporelings were more or less trilobate, and the lobes became deeper in subsequent leaves as the plant grew. Moreover, in plants of these latter populations, glandular hairs were present on the petiole and on the lamina, at least until the stage when three or four leaves had developed; this happened also in plants of the SOL population.

The cluster analysis yielded two clearly different main groups, and each was separated again into two minor groups (Fig. 18). In the upper branch, the first group was made up by the CAM, GRA, BER, and SOM populations (A. celtibericum ssp. celtibericum), and the second included only the SOL population (A. celtibericum ssp. molinae). The lower branch included, in one group, the LOM, LOG, and FON populations (A. seelosii ssp. seelosii) and, in the other, the BAG and ORG populations (A. seelosii ssp. catalaunicum).

\section{DISCUSSION}

The development of the prothallus with unicellular not secretory hairs was uniform in all the studied populations, and corresponds to the Aspidium type (Nayar \& Kaur, 1971). Nevertheless, a single difference was found in the Italian populations, LOM, FON, and LOG (A. seelosii ssp. seelosii), in which the first hair appeared in the filamentous stage, whereas, in the rest of the populations, the development of hairs was delayed until the bidimensional stage. In some species, both types of development have been seen within the same genetically identical clone in response to different culture conditions (Dyer \& King, 1979). However, in our study, the same culture conditions were applied and, in our opinion, these developmental differences observed between populations are not of taxonomic relevance.

The differences in marginal hair length clearly separate the FON, LOG, and LOM populations (A. seelosii ssp. seelosii) from all the others. Between the rest of the populations, the differences, although significant, are smaller. The mean values in the BAG and ORG populations (A. seelosii ssp. catalaunicum) are higher than those in the SOL population (A. celtibericum ssp. molinae), which has an intermediate value between these and the BER, CAM, GRA, and SOM populations (A. celtibericum ssp. celtibericum). 
A: CAM
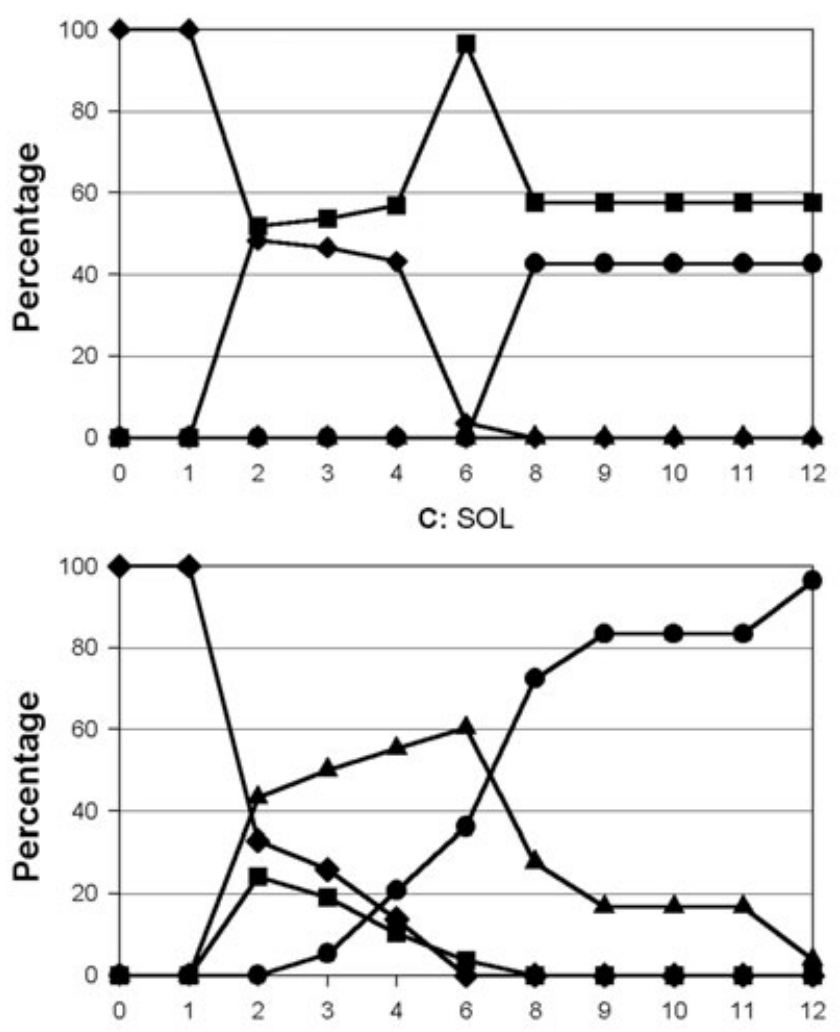

E: ORG

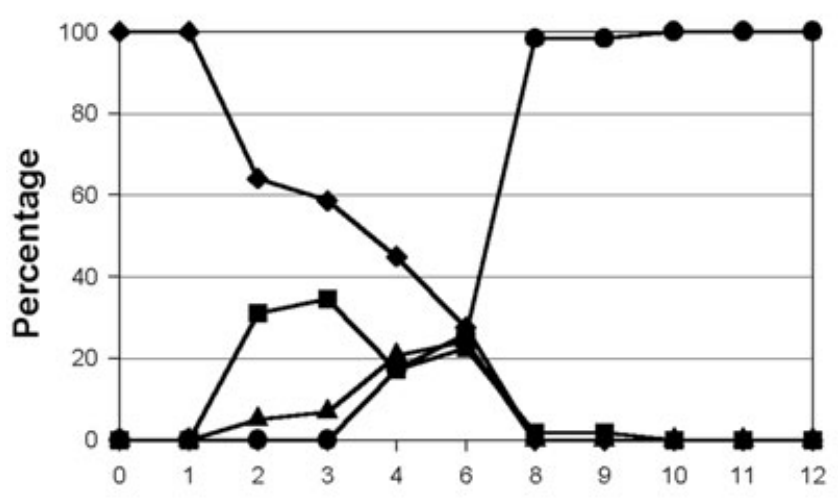

Months
B: GRA
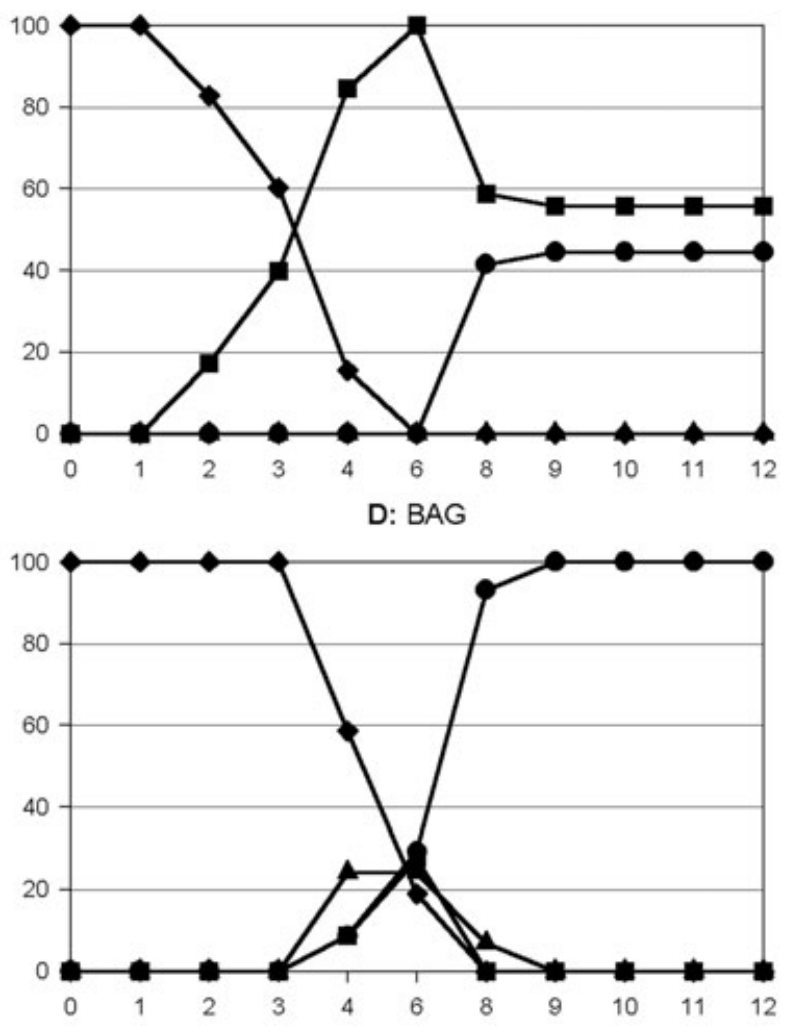

F: LOM

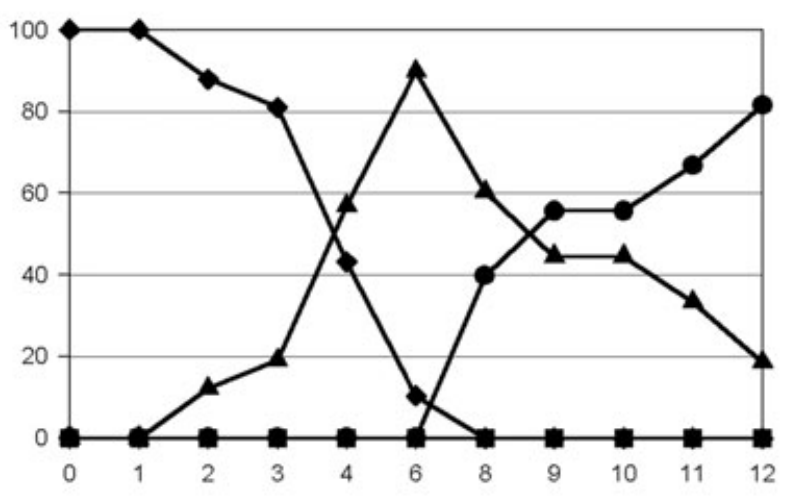

Months

Figure 15. Sex expression of six of the studied populations. A, B, CAM and GRA populations (Asplenium celtibericum ssp. celtibericum). C, SOL population (A. celtibericum ssp. molinae). D, E, BAG and ORG populations (A. seelosii ssp. catalaunicum). F, LOM population (A. seelosii ssp. seelosii). Diamonds, presexuals; squares, males; triangles, females; circles, bisexuals.

All the populations and taxa studied are diploids; thus, in this complex, hair length variation is not related to ploidy level, as happens in many other complexes of Asplenium. Most comparative studies of gametophyte hair length have been made in groups of polyploids and their parental diploids. Herrero, Prada \& Pajarón (2002) found that hair length was scarcely longer in the allotetraploid A. foreziense than in its parent A.fontanum, whereas the other parent, A. obovatum, lacked hairs in the prothallus. In that study, the authors also compared two diploid taxa, A. fontanum and A. pseudofontanum, and found similar mean values for their hair lengths. However, the separation of these into two different taxa is not clear 


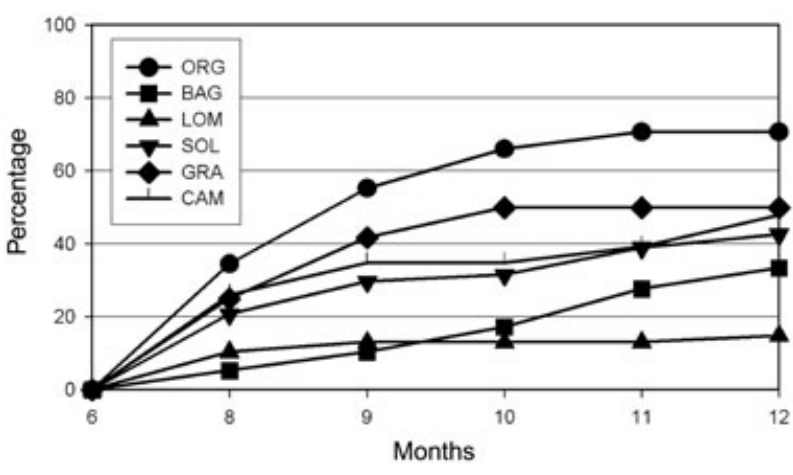

Figure 16. Percentage of archegoniate gametophytes bearing embryos or sporelings.
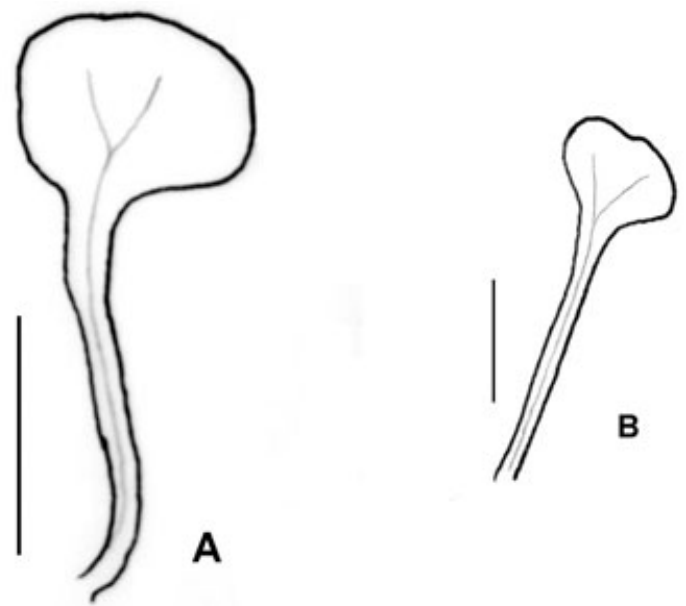

\section{A}
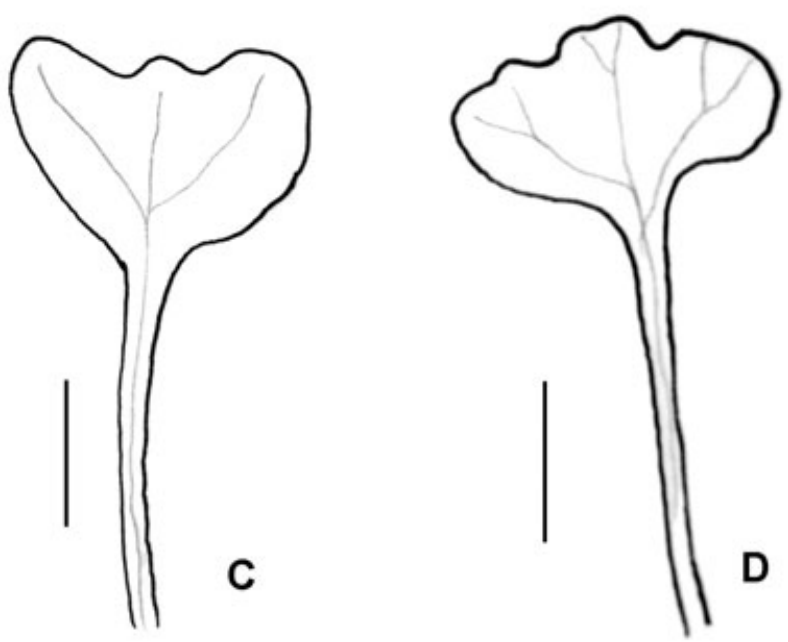

Figure 17. First leaves of the sporelings: A, from BER population (Asplenium celtibericum ssp. celtibericum); B, from SOL population (A. celtibericum ssp. molinae); C, from BAG population (A. seelosii ssp. catalaunicum); D, from LOM population (A. seelosii ssp. seelosii). Scale bar, $2 \mathrm{~mm}$.

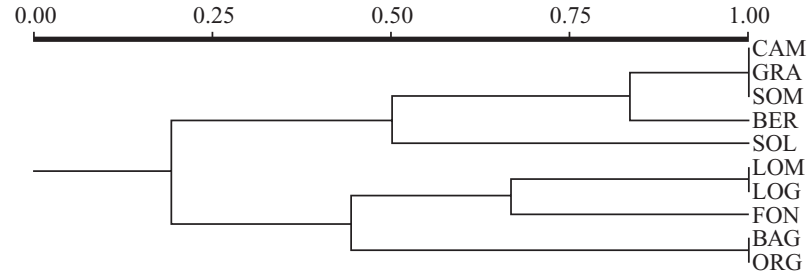

Figure 18. Dendrogram based on the morphological characters of gametophytes and sporelings.

and requires further investigation (Herrero et al., 2002). In the A.adiantum-nigrum complex, the mean value of the tetraploid is intermediate between both parents, A. onopteris with longer hairs and A. cuneifolium with shorter hairs (Prada et al., 1995). Tetraploids of the A. trichomanes complex, considered to be autopolyploids, have longer hairs than the diploid members of the group (Herrero et al., 1993). In many other comparative studies of the gametophytic generation, only the presence or absence of hairs and/ or the type (i.e. glandular, unicellular, pluricellular, etc.) are used, and no references are made to differences in hair length between taxa or populations (Pérez-García et al., 1999, 2001; Pacheco \& Riba, 2003).

On the other hand, the mean values of hair length decrease with latitude. The FON, LOG, and LOM populations, from Italy, the northernmost ones, are well discriminated by this character and show the highest values. The southernmost populations, BER, CAM, GRA, and SOM (A. celtibericum ssp. celtibericum), have the shortest hairs. The BAG and ORG, and SOL populations, which have intermediate values, all live in the Pyrenees area, and thus also have an intermediate latitudinal position between the other two groups of populations. A similar variation correlated with latitude was found by Cubas et al. (1993) for the glandular hairs of the sporophyte.

With regard to gametophyte hair density, the populations showed significant differences, but these were not consistent with their classification at the species or subspecies level. This character may be less genetically determined than hair length.

The shape of the apical notch accounts for the differentiation of the Iberian populations (BER, CAM, GRA, and SOM populations; A. celtibericum ssp. celtibericum), in which it is V-shaped, from the rest of the populations, in which it is U-shaped. The length of the archegonium neck is a character that differentiates the Italian populations (FON, LOG, and LOM; A. seelosii ssp. seelosii), in which the neck is eight to nine cells long, from the other populations, in which it is four to five cells long. In Asplenium, differences in archegonium neck length were shown by Momose 
(1960) and Nayar et al. (1968), who found long necks of five to six cells in A. adiantum-nigrum, and short necks with only four cells in A. tenuifolium. In leptosporangiate ferns as a whole, long archegonium necks are considered to be an ancestral condition against shorter necks (Stokey, 1951; Atkinson \& Stokey, 1964). Nayar \& Kaur (1971) showed neck lengths between seven and 12 cells only in primitive families, such as Cyatheaceae, Gleicheniaceae, or Osmundaceae, whereas, in more advanced ferns, this number was reduced to four or five cells. Our results may indicate the primitive character of the gametophyte of A. seelosii ssp. seelosii.

The sex sequence also showed differences between populations. In the populations corresponding to A. celtibericum ssp. celtibericum (CAM and GRA), the initially male prothalli became bisexual by the formation of archegonia. This sex sequence is common in species of Asplenium (Pangua, Lindsay \& Dyer, 1994; Prada et al., 1995; Aragón \& Pangua, 2003), and is interpreted as an adaptation that facilitates selfing (Klekowski \& Lloyd, 1968; Klekowski, 1969). In the rest of the populations, the sexual sequence was more complex. The prothalli finally reached bisexuality, but there was a previous stage in which male, female, and bisexual prothalli coexisted in different proportions. These proportions were similar in the BAG and ORG populations (A. seelosii ssp. catalaunicum), but there was a higher percentage of females in the SOL (A. celtibericum ssp. molinae) and LOM (A. seelosii ssp. seelosii) populations after 6 months of culture, when sporophytes began to appear. Theoretically, the existence of a long archegoniate stage facilitates intergametophytic crossing (Klekowski, 1969), but, as pointed out by Lloyd (1974), the reproductive system cannot be established only by sex expression. However, in our cultures, the gametophytes were monitored and we were able to check that all fertilized prothalli were bisexual. All of these populations were included in the isoenzymatic study of Pajarón et al. (2005) and, although this study was made with a systematic purpose, within-population variation was not detected. Low intrapopulation genetic diversity is not uncommon in ecologically restricted fern species that are adapted to peculiar habitats, i.e. bare rock faces, and has been related to intragametophytic selfing (Holbrook-Walker \& Lloyd, 1973; Lloyd, 1974; Schneller \& Holderegger, 1996).

Sporophyte formation was synchronous and began 6 months after sowing. The development of gametangia and fertilization showed a significant delay compared with other diploid Asplenium species, such as A. scolopendrium and A. onopteris (Pangua et al., 1994; Prada et al., 1995). In these species, gametangia appeared after 1 or 1.5 months, and the first sporophytes were observed 3 months after sowing. Perhaps this delay is related to a low reproduction rate that might explain the small population sizes in this complex (E. Pangua, L. G. Quintanilla and S. Pajarón, unpubl. data). Features such as slow-growing gametophytes and predominant inbreeding could explain the lack of evolutionary success of ecologically restricted species (Holbrook-Walker \& Lloyd, 1973). The development of vegetative proliferations in the gametophytes may be a result of the mentioned delay in fertilization, and would provide new gametangia and facilitate reproductive success. The development of these vegetative colonies is sometimes related to polyembryony, and agrees with the results of Aragón \& Pangua (2003) in A. septentrionale and Cousens (1979) in Blechnum spicant. However, in these studies, cultures consisted of isolated or paired gametophytes instead of multispore cultures. The density of our multispore cultures, about one prothallus per square centimetre, might be low enough for the prothalli to behave as if they were isolated. Fertilization is not easy under these conditions, and the development of proliferations may guarantee intragametophytic selfing.

The first leaves of sporelings also showed differences between populations. Young leaves are bilobate in populations from the Iberian Peninsula (BER, CAM, GRA, and SOM) and in the SOL population from the central Pyrenees, all five included in A. celtibericum. Sporeling leaves are trilobate in populations from Italy (FON, LOG, and LOM) and from the eastern Pyrenees (BAG and ORG), all belonging to A. seelosii.

One of the characters most frequently used in this complex for the differentiation of taxa is the presence or absence of glandular hairs in adult sporophytes (Rivas-Martínez, 1967; Reichstein, 1984; Cubas et al., 1993; Viane et al., 1993; Prelli, 2001). Nevertheless, this does not hold true when considering young sporophytes. Only populations corresponding to A. celtibericum ssp. celtibericum are completely glabrous, whereas all the other populations have more or less glandular hairs on petioles and even on the lamina, at least until three or four leaves are produced.

When considering the characters of the gametophytes and sporelings together in the cluster analysis, two main groups of populations were obtained (Fig. 18). Although differences are subtle, the dendrogram fits well with the species delimitation proposed by Cubas et al. (1993). All the populations in the upper part of the tree correspond to A. celtibericum according to the morphological and biogeographical criteria of Cubas et al. (1993), whereas the populations in the lower branch correspond to A. seelosii. The northernmost populations, FON, LOG, and LOM (A. seelosii ssp. seelosii), from the Alps, are well differentiated, as are the southern populations of the Iberian Peninsula, 
BER, CAM, GRA, and SOM (A. celtibericum ssp. celtibericum). The intermediate position of the Pyrenean populations can be deduced from the analysis of the characters discussed above. Moreover, geographically, they are also located between the other two groups of populations, the Alps (more than $800 \mathrm{~km}$ to the nearest populations) and the Iberian Peninsula (more than $300 \mathrm{~km}$ ). As hypothesized by Pichi Sermolli (1979), and supported by their long archegonial necks, the populations of the Alps could be the oldest, and from there they would have extended southwards. The intermediate morphological and geographical position of the Pyrenean populations agrees with this phylogeographical hypothesis. The use of molecular techniques would be a good instrument to assess this question.

Although the genetic data obtained by Pajarón et al. (2005) support the separation of the two species, A. seelosii and A. celtibericum, they do not support the separation of the subspecies in each. The differences found in the character of the gametophytes and sporelings, in our opinion, are not sufficiently strong to support the subdivision into infraspecific taxa.

\section{ACKNOWLEDGEMENTS}

We are grateful to Ronnie Viane for comments, suggestions and help with the English, and to Adrian Dyer for criticism and comments on the manuscript. Thanks also go to Carlo Argenti for collecting plants in Italy, and to Adalberto, Cleo and Gabriele Peroni for leading us to the collection of more Italian plants. This study was funded by the Dirección General de Ciencia y Tecnología, project PB97-0307.

\section{REFERENCES}

Aragón CF, Pangua E. 2003. Gender determination and mating system in the autotetraploid fern Asplenium septentrionale (L.) Hoffm. Botanica Helvetica 113: 181-193.

Atkinson RL, Stokey AG. 1964. Comparative morphology of the gametophyte of homosporous ferns. Phytomorphology 14: $51-70$.

Chiou W-L, Farrar DR, Ranker TA. 1998. Gametophyte morphology and reproductive biology in Elaphoglossum. Canadian Journal of Botany 76: 1967-1977.

Cousens MI. 1979. Gametophyte ontogeny, sex expression, and genetic load as measures of population divergence in Blechnum spicant. American Journal of Botany 66: 116132.

Cubas P, Pardo C, Rivas-Martínez S. 1993. The Asplenium seelosii aggr. (Aspleniaceae, Pteridophyta): morphology, cytology, ecology and taxonomy. Rivasgodaya 7: 99-117.

Dyer AF. 1979. The culture of fern gametophytes for experimental investigation. In: Dyer AF, ed. The experimental biology of ferns. London: Academic Press, 253-305.

Dyer AF, King MAL. 1979. Cell division in fern protonemata.
In: Dyer AF, ed. The experimental biology of ferns. London: Academic Press, 307-354.

Edwards ME, Miller JH. 1972. Growth regulation by ethylene in fern gametophytes III. Inhibition of spore germination. American Journal of Botany 59: 458-465.

Herrero A, Prada C, Pajarón S. 2002. Gametophyte morphology and gametangial ontogeny of Asplenium foreziense and related taxa (Aspleniaceae: Pteridophyta). Botanical Journal of the Linnean Society 139: 87-98.

Herrero A, Prada C, Pangua E, Escudero A, Rubio A, Pajarón S. 1993. Gametophyte morphology of four subspecies of Asplenium trichomanes. Botanica Complutensis 18: 67-77.

Holbrook-Walker SG, Lloyd RM. 1973. Reproductive biology and gametophyte morphology of the Hawaiian fern genus Sadleria (Blechnaceae) relative to habitat diversity and propensity for colonization. Botanical Journal of the Linnean Society 67: 157-174.

Klekowski EJ. 1969. Reproductive biology of the Pteridophyta. Theoretical considerations. Botanical Journal of the Linnean Society 62: 347-359.

Klekowski JE, Lloyd RM. 1968. Reproductive biology of the Pteridophyta. I. General consideration and a study of Onoclea sensibilis L. Botanical Journal of the Linnean Society 60: $315-324$.

Lloyd RM. 1974. Mating systems and genetic load in pioneer and non-pioneer Hawaiian Pteridophyta. Botanical Journal of the Linnean Society 69: 23-35.

Lovis JD. 1987. Hybridisation experiments between Asplenium seelosii and A. celtibericum (=A. seelosii ssp. glabrum) (Aspleniaceae, Pteridophyta). Fern Gazette 13: 151-156.

Mendoza-Ruiz A, Pérez-García B. 2003. Comparative analysis of the sexual phase of Phanerophlebia (Dryopteridaceae) in Mexico. Canadian Journal of Botany 81: 501-516.

Momose S. 1960. The prothallia of Aspleniaceae. III. Journal of Japanese Botany 35: 47-54.

Nayar BK, Kaur S. 1971. Gametophytes of homosporous ferns. Botanical Review 37: 295-396.

Nayar BK, Raza F, Lata P. 1968. Gametophytes of some Indian spleenworts. Phytomorphology 18: 467-478.

Nogueira I, Ormonde J. 1986. Asplenium L. In: Castroviejo S, Laínz M, López González G, Montserrat P, MuñozGarmendia F, Paiva J, Villar L, eds. Flora Iberica, Vol. I. Lycopodiaceae-Papaveraceae. Madrid: Real Jardín Botánico, CSIC, 90-104.

Pacheco L, Riba R. 2003. Gametófitos de nueve especies de Callipteris y su comparación con otros géneros de la familia Woodsiaceae. Revista de Biología Tropical 51: 49-58.

Pajarón S, Quintanilla LG, Pangua E. 2005. Isozymic contribution to the systematics of the Asplenium seelosii group. Systematic Botany 30 (1): 52-59.

Pangua E. 1989. Estudios palinológicos en Pteridófitos ibéricos: Familia Aspleniaceae. Unpublished DPhil Thesis, Universidad Complutense de Madrid.

Pangua E, Lindsay S, Dyer A. 1994. Spore germination and gametophyte development in three species of Asplenium. Annals of Botany 73: 587-593.

Pangua E, Quintanilla LG, Sancho A, Pajarón S. 2003. A 
comparative study of the gametophytic generation in the Polystichum aculeatum group (Pteridophyta). International Journal of Plant Sciences 164: 295-303.

Pérez-García B, Mendoza A, Reyes I, Riba R. 1999. Morfogénesis de la fase sexual de seis especies mexicanas de helechos del género Dryopteris (Dryopteridaceae). Revista de Biología Tropical 47: 69-81.

Pérez-García B, Mendoza A, Reyes I, Riba R. 2001. Morfogénesis de la fase sexual de seis especies mexicanas del género Dryopteris (Dryopteridaceae), parte II. Revista de Biología Tropical 49: 265-278.

Pichi Sermolli REG. 1979. A survey of the pteridological flora of the Mediterranean Region. Webbia 34: 175-242.

Prada C, Pangua E, Herrero A, Pajarón S. 1996. A comparative study of the gametophytes of Asplenium majoricum Litard. (Aspleniaceae) and related taxa. Anales del Jardín Botánico de Madrid 54: 126-136.

Prada C, Pangua E, Pajarón S, Herrero A, Escudero A, Rubio A. 1995. A comparative study of gametophyte morphology, gametangial ontogeny and sex expression in the Asplenium adiantum-nigrum complex (Aspleniaceae, Pteridophyta). Annales Botanici Fennici 32: 107-115.

Prelli R. 2001. Les fougeres et plantes alliees de France et d'Europe occidentale. Paris: Éditions Belin.

Pryer KM, Haufler CH. 1993. Isozymic and chromosomal evidence for the allotetraploid origin of Gymnocarpium dryopteris (Dryopteridaceae). Systematic Botany 18: 150-172.

Raghavan V. 1989. Developmental biology of fern gametophytes. Cambridge: Cambridge University Press.

Ranker TA, Haufler CH, Soltis PS, Soltis DE. 1989. Genetic evidence for allopolyploidy in the neotropical fern Hemionitis pinnatifida (Adiantaceae) and the reconstruction of an ancestral genome. Systematic Botany 14: 439447.

Reichstein T. 1984. Aspleniaceae. In: Conert HJ, Hamann U,
Schultze-Motel W, Wagenitz G, eds. Gustav Hegi illustrierte flora von mitteleuropa. Band 1, Pteridophyta. Teil 1. Berlin: P. Parey, 211-275.

Rivas-Martínez S. 1967. Une espèce nouvelle d'Asplenium (Aspleniaceae) d'Espagne. Bulletin du Jardin Botanique National de Belgique 37: 329-334.

Rohlf FJ. 1994. NTSYS-pc. Numerical taxonomy and multivariate analysis system, version 1.80. Setauket, NY: Exeter Software.

Rothmaler W. 1937. Criptògames vasculares o Pteridóphites. In: Cadevall J, Font i Quer P, eds. Flora de Catalunya. Barcelona: Institut de Ciències, 315-373.

Schneller JJ, Holderegger R. 1996. Genetic variation in small, isolated fern populations. Journal of Vegetation Science 7: 113-120.

SPSS. 1999. SPSS para Windows, version 10.0.6. Chicago, Illinois: SPSS Inc.

Stokey AG. 1951. The contribution by the gametophyte to classification of the homosporous ferns. Phytomorphology 1: $39-58$.

Van den heede CJ, Viane RLL, Chase MW. 2003. Phylogenetic analysis of Asplenium subgenus Ceterach (Pteridophyta: Aspleniaceae) based on plastid and nuclear ribosomal ITS DNA sequences. American Journal of Botany 90: 481495.

Viane RLL, Jermy AC, Lovis JD. 1993. Asplenium. In: Tutin TG, Burges NA, Chater AO, Edmonson JR, Heywood VH, Moore DM, Valentino DH, Walters SM, Webb DA, eds. Flora Europaea. Vol. I: Psilotaceae to Platanaceae, 2nd edn. Cambridge: Cambridge University Press, 18-23.

Werth CR, Guttman SI, Eshbaugh WH. 1985. Electrophoretic evidence of reticulate evolution in the Appalachian Asplenium complex. Systematic Botany 10: 184-192.

Zar JH. 1996. Biostatistical analysis, 3rd edn. Englewood Cliffs, NJ: Prentice Hall. 